\title{
RANCANG BANGUN PROTOTYPE ALAT DETEKSI GETARAN
}

\author{
Iip Muhlisin, S.T., M.T. \\ Prodi Teknik Industri Fakultas Teknik Universitas Pamulang, Tangerang Selatan Banten 15417, Indonesia, \\ dosen01937@unpam.ac.id
}

\begin{abstract}
ABSTRAK
Di dunia Industri sering terjadi keruksakan mekanis pada mesin mesin yang berputar. Getaran ditemukan hampir di semua tempat pada mesin berputar. Mesin berputar bergetar karena ketidakseimbangan, ketidaksejajaran, dan bagian yang tidak sempurna. Pendekatan analitik telah menunjukkan bahwa pemantauan getaran memiliki potensi luar biasa dalam mendeteksi dan melokalisasi cacat pada mesin. Kecepatan getaran dan beban getaran akan diukur pada kecepatan yang berbeda menggunakan FFT (Fast Fourier Transform) pada kondisi awal.

Berdasarkan analisis spektrum pembacaan getaran dan analisis fase dilakukan untuk menentukan penyebab getaran tinggi. Dengan mengamati spektrum ketidakseimbangan akan diidentifikasi. Kemudian Rotor seimbang dan menemukan bahwa getaran berkurang. Spektrum frekuensi eksperimental diperoleh untuk kondisi seimbang dan tidak seimbang di bawah gaya tidak seimbang yang berbeda pada kondisi kecepatan yang berbeda. Dalam proyek penelitian eksperimental ini, struktur getaran dibangun dalam model skala untuk mensimulasikan getaran dan untuk memantau kinerja sistem dalam hal tingkat getaran dalam kasus rotasi dengan kondisi seimbang dan tidak seimbang. Dalam model berskala ini, sinyal output dari sensor getaran diproses dalam mikrokontroler dan kemudian ditransfer ke komputer. Hasil akhir aktual dari analisis getaran akan diberikan setelah menyelesaikan tes analisis getaran selama berlangsungnya tesis MEE, oleh karena itu hasil grafik pada makalah ini hanya didasarkan pada teori saja.
\end{abstract}

Kata kunci: Analisis Getaran, Fast Fourier Transform, Tidak seimbang, Analisis Spektrum.

\section{PENDAHULUAN}

Ada beberapa metode yang dapat digunakan untuk pemantauan kondisi mesin untuk mendukung keputusan perawatan. Dalam analisis karakteristik mekanik memungkinkan penggunaan sinyal getaran untuk menentukan kondisi mesin tanpa membongkar atau menghentikan mesin, sehingga dapat digunakan untuk analisis lebih lanjut dalam perbaikan kerusakan yang disebabkan. Dengan mengamati analisis getaran secara teratur, maka sesuatu yang tidak normal dalam mesin dapat dideteksi sebelum terjadi kerusakan hebat.

Analisis getaran alat berat menghasilkan beberapa manfaat termasuk peningkatan pendapatan, peningkatan keandalan produksi, lebih sedikit waktu henti, dan biaya perbaikan yang lebih rendah. Analisis ini terkait erat dengan perlindungan. Namun, fungsi utamanya adalah bahwa ia mengarah pada deteksi dini kesalahan tidak seperti perlindungan. Ini sangat membantu untuk menjadwalkan kegiatan dengan mudah mengurangi downtime dan kerugian.

Pemecahan kerusakan dalam industri tidak populer lagi, telah berevolusi dari pemeliharaan kerusakan menjadi pemeliharaan preventif dan prediktif berbasis waktu. Analisis Getaran khususnya untuk beberapa waktu telah digunakan sebagai prosedur perawatan prediktif dan sebagai pendukung untuk keputusan perawatan mesin. Yang terbaik dari prosedur operasional standar, mesin tidak mogok atau gagal tanpa beberapa bentuk peringatan dini, yang ditandai dengan peningkatan level getaran.

Pemantauan secara real time dengan mengukur dan menganalisis getaran mesin, dimungkinkan untuk menentukan sifat dan tingkat keparahan cacat, dan karenanya memprediksi kegagalan mesin. Sinyal getaran over-all dari mesin dikontribusikan dari banyak 
komponen dan struktur yang dapat digabungkan. Namun, kerusakan mekanis menghasilkan getaran karakteristik pada frekuensi yang berbeda, yang dapat dikaitkan dengan kondisi kesalahan mesin tertentu. Dengan menganalisis spektrum waktu dan frekuensi, dan menggunakan teknik pemrosesan sinyal, baik frekuensi cacat maupun alami dari berbagai komponen struktural dapat diidentifikasi.

Dalam tulisan ini, analisis getaran menggunakan FFT dipelajari. Ini dicapai dengan menyelidiki kondisi operasi kecepatan yang berbeda dari mesin listrik berputar. Mesin listrik yang berputar harus dijalankan dalam kondisi operasi normal sebagai uji referensi. Serangkaian tes dilakukan di mana sejumlah cacat mesin yang berbeda sengaja diperkenalkan.

\section{LANDASAN TEORI}

Pada tahun 1960, J. W. Cooley dan J. W. Tukey dapat merumuskan teknik perhitungan yang efisien dari algoritma Fourier Transform. Teknik (FTT) perhitungan algoritma ini dikenal dengan Fast Fourier Transform (FFT) atau lebih dikenal sebagai FFT, yang diperkenalkan oleh JSBendat dan AGPiersol pada tahun 1986. Fast Fourier Transform dalam bahasa Indonesia adalah Fast Fourier Transform adalah sumber algoritma untuk menghitung Discrete Fourier. Transform DFT) dengan cepat, efisien dan inversnya. Pada penelitian ini akan dibuat perakitan experimental deteksi getaran dapat dilihat pada gambar 1 Alat pendeteksi getaran dibawah ini:

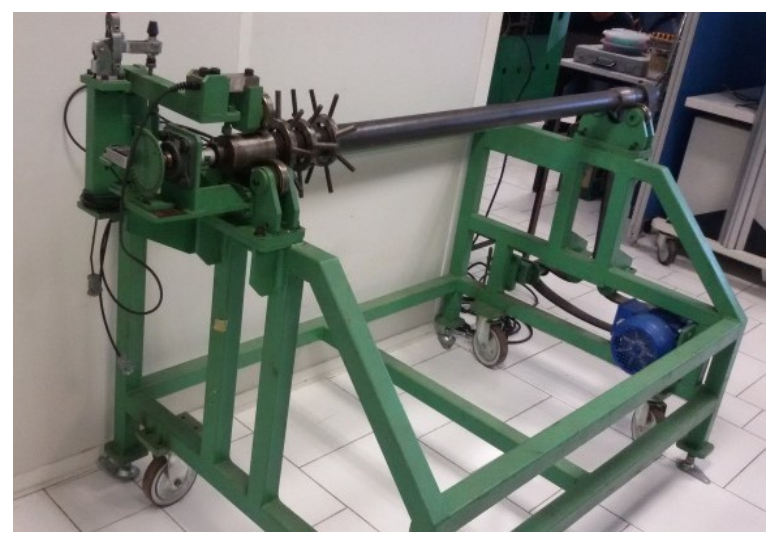

Gambar 1: Alat pendeteksi Getaran
Perakitan eksperimental dengan kondisi pengoperasian yang terkontrol diatur untuk melakukan serangkaian pengujian menggunakan Motor AC 1,5 KW, Inverter Siemen, arduiono artmega 2560. Ikat Pinggang, poros rotor, sel beban Vishay, Photo Sensor SUB-30. Foto alat pendeteksi getaran ditunjukkan pada gambar. 1 .

Desain sistem pendeteksi getaran terdiri dari desain perangkat keras dan perangkat lunak. Pengontrol mikro ARTMEGA 2560 menyediakan Analog digital Converter (ADC) dan komunikasi port ke komputer, aplikasi program perangkat lunak QT yang berisi program perangkat lunak yang berfungsi untuk memproses pengumpulan data getaran dan getaran pemrosesan data yang menggunakan FFT. Desain sistem perangkat keras dapat dijelaskan dalam bentuk diagram blok perangkat keras seperti yang ditunjukkan pada Gambar 2 berikut ini:

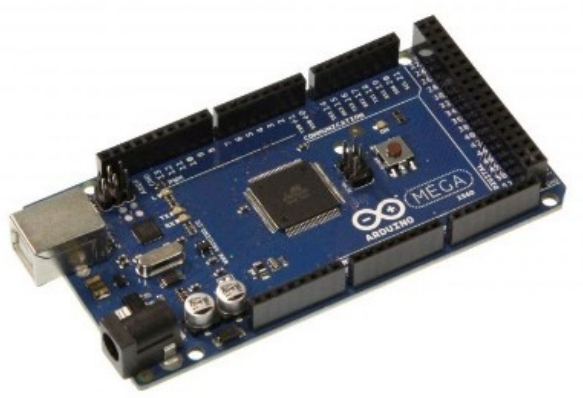

Gambar 2. Arduino Artmega 2560

Aplikasi program perangkat lunak QT dapat dilihat gambar 5 Program Aplikasi QT berikut:

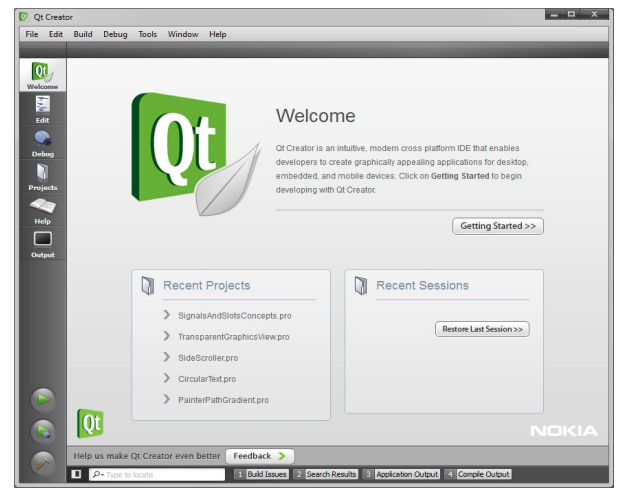

Gambar 5. Program Aplikasi QT

Sensor yang digunakan adalah sensor Vishay loadcell. Sensor ini dilengkapi dengan tool mekanis lainnya yaitu toggle clamp dan ball 
bearing dipasang langsung pada pada Poros Rotor atau silinder berputar, seperti yang terlihat pada Gambar 6. Instalasi Vishay loadcell berikut:

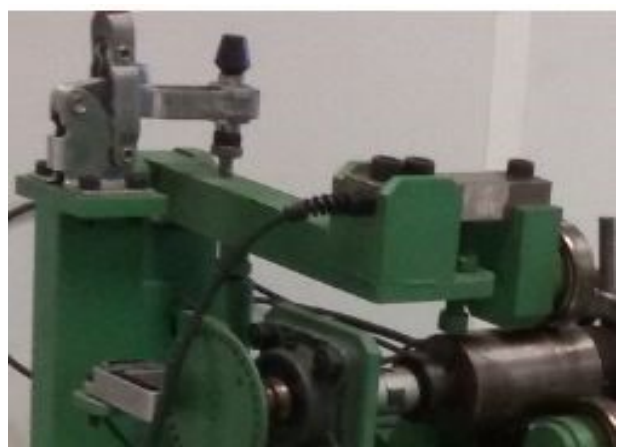

Gambar 6. Instalasi Vishay loadcell

Sensor yang digunakan adalah sensor Vishay loadcell. Sensor ini mengukur Kekuatan getaran langsung dari poros rotor dan kemudian gaya akan dikonversi menjadi tegangan, Tegangan akan dikirim ke mikrokontroler untuk mengkonversi dari analolog ke data digital, data digital akan diproses menjadi spektrum dengan menggunakan Fast Fourier Transport di Komputer dapat dilihat pada gambar 7 Diagram Analisis dan Harware yang digunakan.

Rotating Equipment

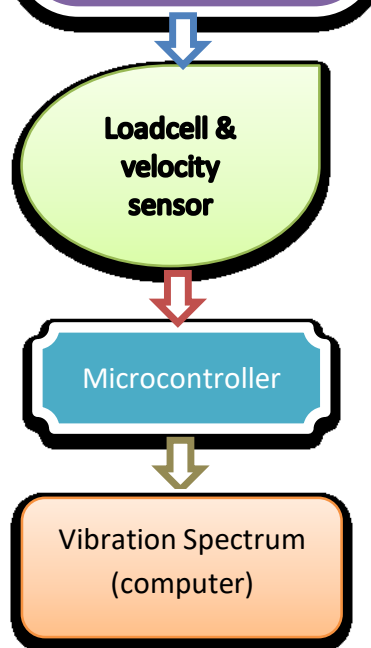

Gambar 7 Diagram Analisis dan Harware yang digunakan

Pada Prototype alat deteksi getaran ini telah dipasang Micromaster Vector Siemen Inverter yang diperlihatkan dalam Gambar. 8 yang berfungsi untuk mengontrol kecepatan putar dari Yuema AC Motor 1,5 KW yang diperlihatkan dalam gambar 9, sehingga Poros Rotor (silinder) dapat diatur kecepatanya yang akan digunakan selama test analyis pada keceptan yang berbeda-beda.

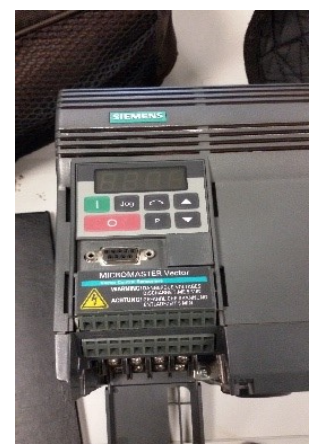

Gambar 8. Micromaster Vector Siemen Inverter

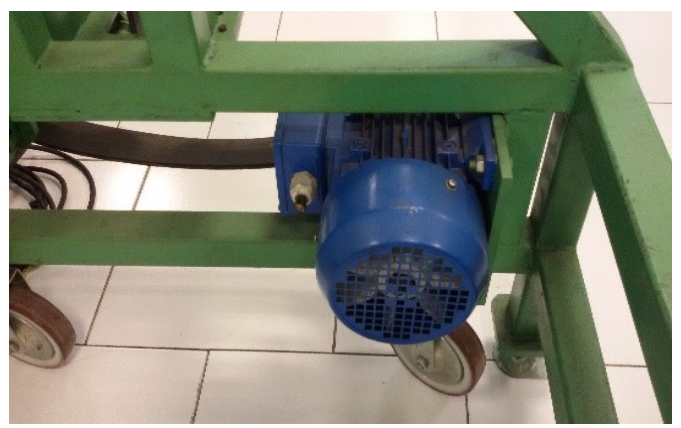

Gambar 9. Yuema AC Motor 1,5 KW

Selain itu telah dipasang juga Photo Sensor diperlihatkan pada Gambar 10. yang digunakan untuk menerima sinyal dari Disc encoder yang diperlihatkan pada Gambar 11, yang berguna untuk mengukur kecepatan poros rotor (silinder).

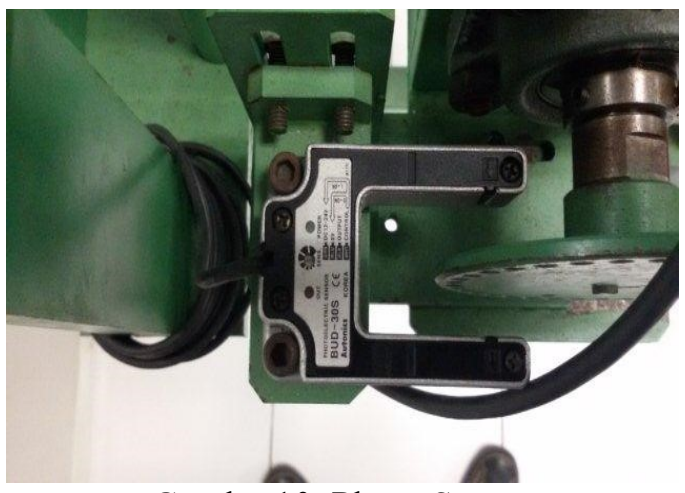

Gambar10. Photo Sensor

Disc dilengkapi dengan lubang lubang dengan jarak jarak dan sudut yang sama terhadap titik pusatnya, yang berfungsi untuk menghitung kecepatan RPM pada Poros Rotor atau (silinder) 
Lubang lubang itu akan memotong sinyal dari Photo sensor saat Poros atau (silinder) sedang berputar sehingga akan tercipta sinyal yang terputus dan tersambung kembali dengan periode waktu yang sama pada kecepatan yang sama sesuia dengan kecepatan putar Poros Rotor (silinder).

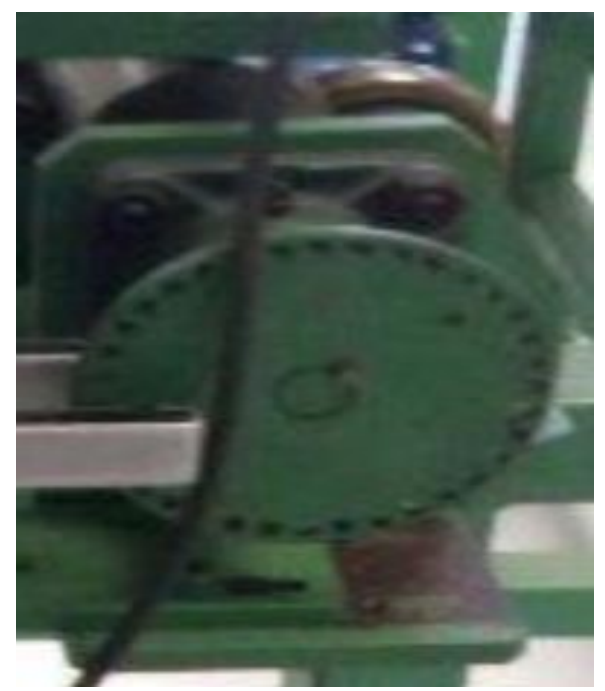

Gambar 11. Disc Encoder

Poros rotor akan dikendarai oleh vektor Micromaster Siemen Inverter dan Motor 1,5 $\mathrm{KW}$, inverter dapat beroperasi untuk menyesuaikan kecepatan motor. Varaint of speed akan digunakan selama test analys. Sensor foto digunakan untuk mendapatkan disc encoder untuk mengukur kecepatan poros rotor. Diagram kabel perangkat pemantauan getaran ditunjukkan pada Gambar 3. Wiring diagram pendeteksi Getaran dibawah ini:

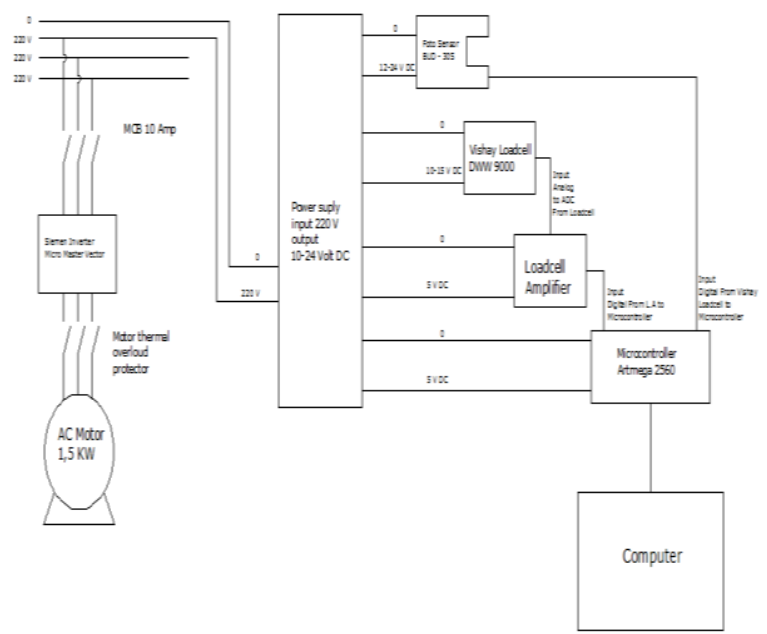

Gambar 3 Wiring diagram pendeteksi Getaran

\section{Metode Dan Teknik Pengukuran}

Ketika komponen-komponen mesin listrik berputar beroperasi terus-menerus pada kecepatan tinggi, aus dan kegagalan akan segera terjadi. Kerusakan dapat dinyatakan bahwa setiap kali satu atau lebih bagian tidak seimbang, tidak selaras, longgar, eksentrik, rusak, atau bereaksi terhadap suatu kekuatan eksternal; mereka menghasilkan tingkat getaran yang lebih tinggi. Getaran yang disebabkan oleh cacat terjadi pada frekuensi getaran tertentu. Amplitudo getaran pada frekuensi tertentu menunjukkan tingkat keparahan cacat.

Analisis getaran bertujuan untuk mengkorelasikan respons getaran sistem dengan cacat spesifik yang terjadi pada mesin, komponennya, bahkan dalam struktur mekanik.

Pada analisis getaran ini, sel beban balok geser digunakan untuk mengukur gaya tidak seimbang yang dihasilkan. Sel beban balok geser Vishay yang digunakan dalam percobaan ini mampu mengukur dari 0 hingga $250 \mathrm{~kg}$.

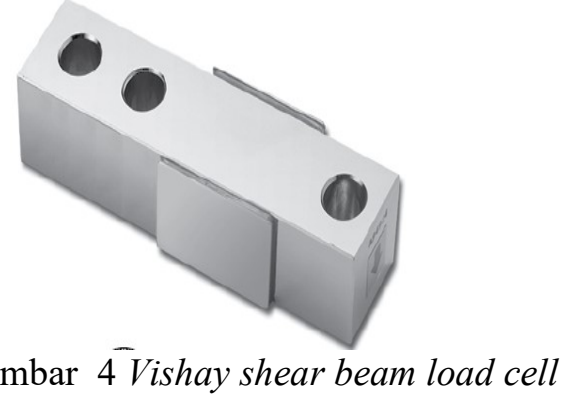

\section{HASIL DAN PEMBAHASAN}

Tes analisis belum dilakukan, tes analisis akan dilakukan untuk proses pengembagan penelitian lebih lanjut, oleh karena itu hasil grafik getaran dibawah hanya berupa teoretis saja dapat dijelaskan berikut:

1. Tes Normal

Sampel spektrum FFT akan diatur pada 500, 900 dan 1500 RPM untuk kondisi kerja normal, tidak ada kesalahan disengaja yang ditunjukkan pada Gambar 5, untuk. Hasil untuk 900. Di bawah ini adalah gambar contoh tidak dalam pengukuran aktual, pengukuran aktual akan dilakukan pada pengembangan penelitian berikutnya. 


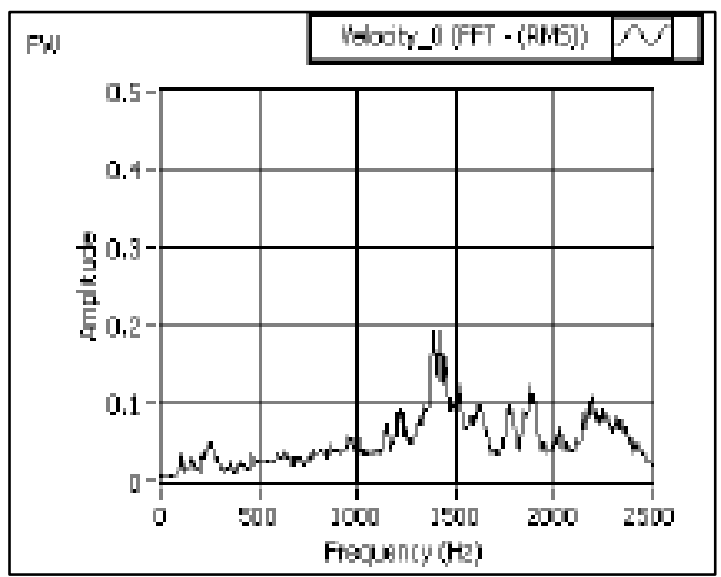

Gambar 5. FFT spectrum Horizontal pada kondisi operasi Normal at 900 RPM tanpa ada keruksakan/keruksakan

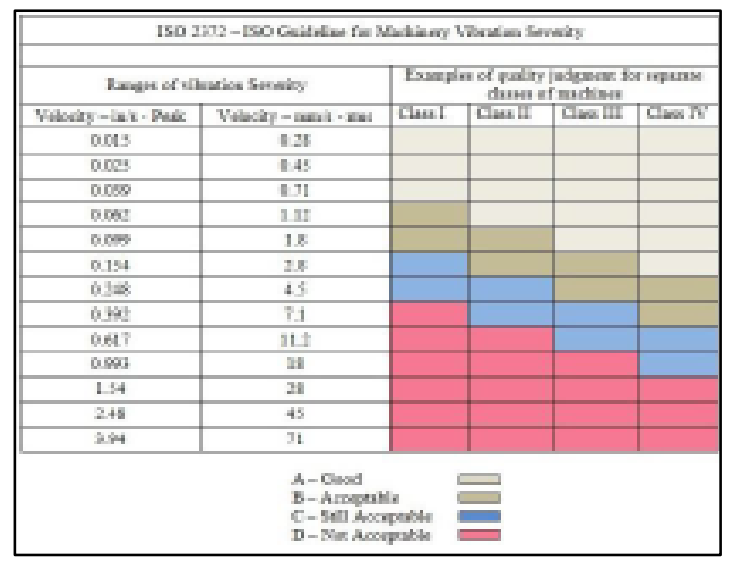

Gambar 6. ISO 2372 vibration standard

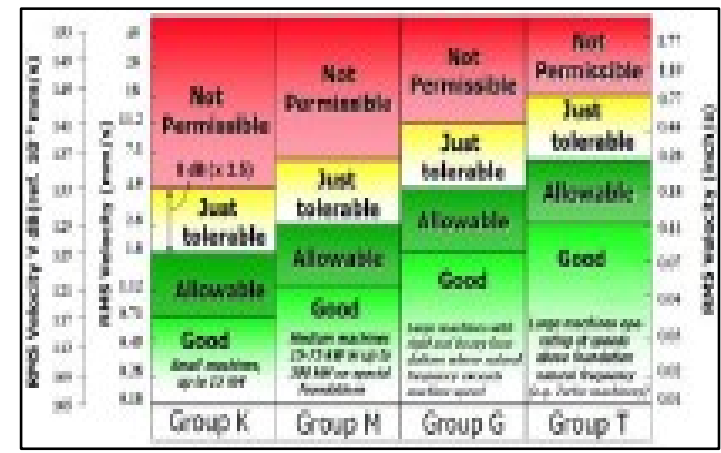

Gambar 7. Standard VDI 2056

2. Tes Tidak Normal (Mesin Cacat)

Ketidakseimbangan diterapkan ke rakitan Protype Alat deteksi getaran dengan menambahkan massa eksternal pada poros rotor. untuk kondisi kerja mesin yang Tidak Normal atau ada keruksakan, maka Grafik Getaran diperlihatkan pada salah satu contoh operasi mesin pada 900 RPM
Gambar 15. FFT Spectrum Operasi Mesin Tidak Normal pada 900 RPM.

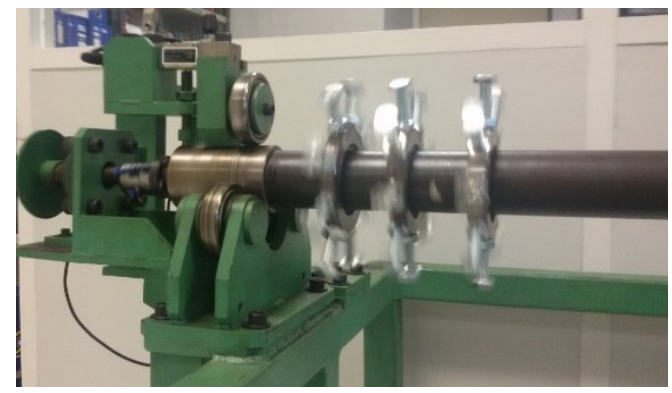

Gambar 14. Penambahan Massa External

Untuk grafik Horizontal FFT spectrum in Unbalance condition at 900 RPM dapat dilihat berikut ini:

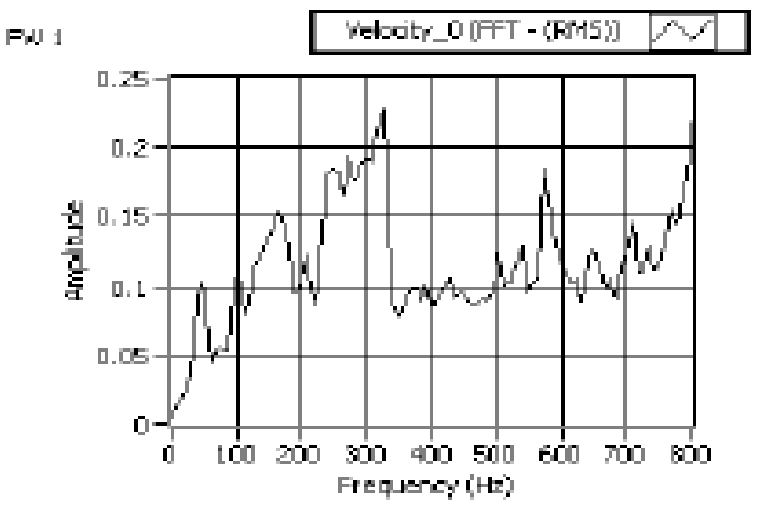

Fig 8. Horizontal FFT spectrum in Unbalance condition at 900 RPM

\section{KESIMPULAN}

1. Memanfaatkan monitor getaran berbasis FFT online, getaran dari mesin dalam kondisi keseimbangan dan ketidakseimbangan dapat dipantau, dikirim, dan diproses secara real time. Ini berarti bahwa bagian mekanik dan listrik berfungsi dengan baik maka dapat ditangkap kondisi kesalahan awal sebelum kerusakan yang lebih serius atau fatal terjadi.

2. Amplitudo magnitudo spektrum frekuensi dapat ditentukan sebagai kondisi operasi Normal atau abnormal mesin berputar.

3. Model kondisi gangguan dapat muncul secara bersamaan dalam pengukuran data spektrum frekuensi.

4. Ketika kecepatan meningkat amplitudo juga akan meningkat untuk berat ketidakseimbangan yang sama. Peningkatan nilai amplitudo ini disebabkan oleh perbedaan 
gaya tak seimbang. Ini akan membuktikan dalam tes Getaran analisis berikutnya selama tesis MME.

\section{REFERESI}

C. Scheffer and Paresh Girdhar, Practical Machinery Vibration Analysis and Predictive Maintenance, Newnes-Elsevier, Oxford 2004.

Ebersbach, Z. Peng and N. J. Kessissoglou, "The investigation of the condition and faults of a spur gearbox.

International Standard, Mechanical Vibration, ISO 2003.

Muhlisin, Iip: Developping Vibration Monitoring System For A Model Cylinder Rotating Machine Using Fast Fourier Transform.

Mok Goh , Yoke SanWong and Geok Soon Hong " Intelligent Prediction Monitoring System for Predictive Maintenance in Manufacturing," Proceedings of the 31st Annual Conference of the IEEE Industrial Electronics Society -IECON'05, North Carolina, USA, 6-10 Nov 2005.

Peng Z., Kessissoglou N., "An integrated approach to fault diagnosis of machinery using wear debris and vibration analysis", Elsevier, Wear 255 (2003), 1221-1232.

Peter Tavner, Li Ran, Jim Penman and Howard Sedding, Condition Monitoring of Rotating Electrical Machines, IET Power and Energy Series, London, UK, 2008.

S. using vibration and wear debris analysis techniques," Wear 260 (2006), Page(s): $16-24$.

VDI 2056: Standards of Evaluation for Mechanical Vibration of machine.

Zulziar, M. (2018). ANALISA MATERIAL BAHAN PEMBUAT SENSOR La0. 67Ba0. 33Mn1-xNixO3 DENGAN
PENAMBAHAN Ni MENGGUNAKAN

FOUR POINT PROBE. TEKNOLOGI:

Jurnal Ilmiah dan Teknologi, 1(1), 1-9. 